\title{
PERAN BADAN PERMUSYAWARATAN DESA DALAM PENYUSUNAN DAN PENETAPAN PERATURAN DESA
}

\author{
Setiawati \\ Fakultas Keguruan dan Ilmu Pendidikan Universitas Pamulang \\ tya.unpam@gmail.com
}

Naskah diterima: 23 Maret 2018, review: 24 Maret 2018, revisi: 27 Maret 2018,

disetujui: 31 Maret 2018.

\begin{abstract}
Abstrak
Tujuan penelitian ini adalah untuk mengetahui peran Badan Permusyawaratan Desa (BPD) dalam penyusunan dan penetapan peraturan desa. Objek penelitian ini adalah BPD desa Tegal Kecamatan Kemang Kabupaten Bogor. Penelitian ini merupakan field research dengan mengambil data menggunakan wawancara dan studi dokumen yang dianalisis secara deskriptif. Hasil penelitian mendapati bahwa BPD belum melaksanakan tugas dan fungsinya secara maksimal karena kurangnya inisiatif dan koordinasi dengan pemerintahan desa dalam membuat rancangan peraturan desa. Hendaknya, BPD Desa Tegal dapat melakukan evaluasi dan mencari solusi atas penyebab kurang maksimalnya peran BPD. Koordinasi antara BPD dengan pemerintah desa harus lebih ditingkatkan sehingga dapat menghasilkan peraturan desa yang lebih baik.
\end{abstract}

Kata-kata kunci: Badan Permusyawaratan Desa (BPD), peran BPD, peraturan desa

\footnotetext{
Jurnal Pendidikan Kewarganegaraan

Journal of Civics and Education Studies

The journal is published by Department of Civic Education

Faculty of Teacher Training and Education

Universitas Pamulang - Indonesia
}

Copyright (C) 2018 | ISSN: 2302-0865 


\section{PENDAHULUAN}

Dalam Undang-Undang Dasar Republik Indonesia Tahun 1945 (UUD RI 1945) pemerintahan daerah diatur dalam Bab VI. Negara Kesatuan Republik Indonesia (NKRI) terdiri dari daerahdaerah provinsi yang di dalamnya terdiri daerah-daerah kabupaten/kota yang terikat dalam suatu wadah negara kesatuan. Wilayah Indonesia dibagi kedalam daerah baik yang bersifat otonom maupun administratif, daerah itu mempunyai pemerintahan, pembagian wilayah dan bentuk susunan pemerintahan yang ditetapkan sesuai Undang-Undang, dalam pembentukan daerah-daerah itu terutama daerah-daerah otonom dan dalam menetukan susunan pemerintahannya harus diingat permusyawaratan dalam system pemerintahan negara dan hak asal-usul dalam daerah - daerah yang bersifat istimewa (asli).

Salah satu bentuk kewenangan yang dapat dilakukan oleh desa adalah pembuatan produk hukum (peraturan desa) untuk menjalankan roda pemerintahan desa yang mengikat warganya sebagai satu kesatuan masyarakat hukum yang wajib ditaati dalam rangka meningkatkan pembangunan desa. Dalam rangka melaksanakan kewenangan yang dimiliki untuk mengatur dan mengurus kepentingan masyarakatnya, dibentuklah Badan Permusyawaratan Desa (BPD) sebagai lembaga legislasi dan wadah yang berfungsi untuk menampung dan menyalurkan aspirasi masyarakat.
Pada Pasal 34 PP Nomor 72 Tahun 2005 Tentang BPD, Badan Permusyawaratan Desa (BPD) berfungsi menetapkan Peraturan desa bersama Kepala Desa, Menampung dan Menyalurkan aspirasi masyarakat. Penetapan peraturan desa dilakukan oleh Badan Permusyawaratan Desa bersama Kepala Desa. Jadi Kepala Desa sebagai lembaga eksekutif ditingkat desa, sedangkan Badan Permusyawaratan Desa sebagai lembaga legislatif ditingkat desa.

Desa merupakan pemerintahan yang terkecil dari NKRI, dalam menjalankan tugasnya desa memerlukan sebuah lembaga yakni BPD sebagai mitra pemerintahan desa yang solid dalam membangun dan mensejahterakan rakyat. Pemerintah Desa dan BPD diharapkan dapat membawa kemajuan dengan memberikan pengarahan, masukan dalam membangun pemerintahan desa menjadi lebih baik terutama dalam penyusunan dan penetapan Peraturan Pemerintah desa.

Desa merupakan bagian dari sub sistem pemerintahan kabupaten atau kota, menurut Solekhan menegaskan: " tidak ada teori dan asas yang membenarkan penyerahan kewenangan atau urusan dari dari pemerintah kabupaten atau kota ke Kepala Desa”. Disisi lain konstitusi juga tidak menetapkan desentralisasi kewenangan desa. Oleh karena itu kewenangan desa itu hanya di dasarkan pada asas rekognisi (pengakuan) dan subsidaritas dan bukan asas desentralisasi. 
Dalam kaitan ini menurut tim penyusun naskah akademik rancangan Undang-Undang tentang desa ada dua jenis kewenangan desa yang utama yaitu: 1) Kewenangan asal-usul yang diakui oleh negara mengelola asset, (sumber daya alam, tanah, wilayah tanah khas desa) dalam wilayah yuridiksi desa membentuk struktur pemerintahan desa dengan mengakomodasi susunan asli menyelesaikan sengketa secraa adat, dan melestarikan adat dan budaya setempat; dan 2) Kewenangan melekat (atribut mengatur dan mengurus kepentingan masyarakat yang berskala local/ desa). Menyelenggarakan pemilihan Kepala Desa mengelola APBDes, membentuk lembaga kemasyarakatan, mengembangkan BUMDes, dan lain lain.

Selain itu ada dua jenis kewenangan (urusan) yang bersifat tambahan yakni kewenangan dalam tugas pembantuan (delegasi) yang diberikan oleh pemerintah. Prinsip dasarnya dalam tugas pembangunan ini hanya menjalankan tugas administratif di bidang pemerintahan dan pembangunan yang diberikan pemerintah. Penyelenggaraan pemerintah desa di era reformasi pada hakikatnya adalah proses demokratisasi dari yang selama orde baru berproses dari atas ke bawah sebaliknya saat ini proses dari bawah keatas yakni dimulai dari desa.

Perubahan paradigma baru tersebut mengakibatkan desa sebagai kualitas kesatuan hukum yang otonom dan memiliki hak serta kewenangan untuk mengatur rumah tangganya sendiri sebagaimana diatur dalam pasal 18 Undang-Undang NRI 1945 antara lain menyebutkan bahwa pembagian daerah Indonesia atas daerah besar dan kecil dengan bentuk dan susunan pemerintahannya ditetapkan dengan Undang-Undang.

Berdasarkan Undang-Undang Nomor 32 Tahun 2004 tentang Pemerintahan Daerah juncto Undang-Undang Nomor 12 Tahun 2008 tentang pemerintahan daerah perubahan atas Undang-Undang Nomor 32 Tahun 2004 Tentang Pemerintahan Daerah, desa tidak lagi merupakan tingkat administrasi dengan tidak lagi menjadi bawahan daerah, melainkan menjadi daerah mandiri, dimana masyarakatnya berhak berbicara atas kepentingan sendiri dan bukan ditentukan dari atas ke bawah.

Berdasarkan Undang-Undang Nomor 23 Tahun 2014 tentang Pemerintahan Daerah, desa adalah desa dan desa adat yang disebut dengan nama lain selanjutnya disebut desa adalah kesatuan masyarakat hukum yang memiliki batasa wilayah yang berwenang untuk mengatur dan mengurus urusan kepentingan masyarakat setempat berdasarkan prakarsa masyarakat, hak asal-usul dan atau hak tradisional yang diakui dan dihormati dalam sistem pemerintahan NKRI.

Sedangkan berdasarkan UndangUndang Nomor 6 Tahun 2014 tentang Desa, Desa adalah desa dan desa adat atau yang disebut dengan nama lain, selanjutnya disebut Desa, adalah kesatuan masyarakat hukum yang memiliki batas wilayah yang berwenang untuk mengatur dan mengurus urusan pemerintahan, kepentingan masyarakat setempat berdasarkan prakarsa masyarakat, hak asal 
usul, dan/atau hak tradisional yang diakui dan dihormati dalam sistem pemerintahan Negara Kesatuan Republik Indonesia.

Desa yang selama ini diperankan sebagai peran pembantu dan objek, bukan menjadi aktor pembantu untuk mendukung perubahan mendasar tentang pemerintahan desa maka dikeluarkan Peraturan Pemerintah No. 72 tahun 2005 Tentang Desa dan peraturan daerah kabupaten bogor tentang desa, dimana BPD merupakan perwujudan demokrasi dalam penyelenggaraan pemerintahan desa.

Keberadaan sebuah desa memiliki keanekaragaman yang disesuaikan dengan asal-usul budaya yaitu: 1) Keanekaragaman, disesuaikan dengan asal-usul dan kondisi sosial budaya masyarakat setempat; 2) Partisipasi, bahwa penyelenggaraan pemerintahan dan pembangunan desa harus mampu mewujudkan peran aktif masyarakat agar masyarakat senantiasa memiliki dan turut serta bertanggung jawab terhadap perkembangan kehidupan bersama sebagai sesama warga desa; 3) Otonomi asli, bahwa kewenangan pemerintah desa dalam mengatur dan mengurus masyarakat setempat didasarkan pada hak asal-usul dan nilai-nilai sosial budaya yang terdapat pada masyarakat setempat namun harus diselenggarakan dalam perspektif administrasi desa; dan 4) Demokrasi, artinya penyelenggaraan pemerintahan dan pelaksana pembangunan di desa ditujukan untuk meningkatkan taraf hidup dan kesejahteraan masyarakat melalui penetapan kebijakan program an kegiatan yang sesuai dengan pokok masalah dan prioritas kebutuhan masyarakat.

Pemerintah desa harus melaksanakan peraturan perundang-undangan yang berkaitan dengan desa, akan tetapi peraturan perUndang-Undangan itu tidak bisa langsung dilaksanakan, hal ini karena desa berbeda kondisi sosial, politik dan budayanya.

Dalam proses pengambilan keputusan di desa dilakukan dengan dua macam keputusan. Pertama, keputusan yang beraspek sosial, yang mengikat masyarakat secara sukarela tanpa sanksi yang jelas. Kedua, keputusan keputusan yang dibuat oleh lembaga-lembaga formal desa yang dibentuk untuk melakukan fungsi pengambilan keputusan UndangUndangan bentuk keputusan pertama banyak dijumpai dalam kehidupan sosial masyarakat desa, proses pengambilan keputusan dilakukan melalui proses persetujuan bersama dimana sebelumnya alasan-alasan untuk pemilihan alternatif diuraikan terlebih dahulu oleh para tetua desa ataupun orang yang dianggap memiliki kewibawaan tertentu.

Adapun pada bentuk kedua keputusan-keputusan didasarkan pada prosedur yang telah disepakati bersama seperti musyawarah pembangunan desa (musbangdes) yang dilakukan setiap setahun sekali di Balai Desa. Proses pengambilan keputusan tersebut dilakukan oleh pihak-pihak secara hukum memang diberi fungsi untuk itu yang kemudian disebut dengan peraturan desa atau perdes.

Peraturan desa adalah produk hukum yang ditetapkan oleh Kepala Desa 
bersama BPD dalam rangka penyelenggaraan pemerintahan desa. Peraturan desa merupakan penjabaran lebih lanjut dari peraturan perUndangUndangan yang lebih tinggi dengan memperhatikan kondisi sosial budaya masyarakat desa setempat.

BPD berfungsi menetapkan peraturan desa bersama Kepala Desa, menampung dan menyalurkan aspirasi masyarakat, oleh karenanya BPD sebagai badan permusyawaratan yang berasal dari masyarakat desa disamping menjalankan fungsinya sebagai jembatan penghubung antara Kepala Desa dengan masyarakat desa juga harus melaksanakan fungsi utamanya yakni fungsi representasi (perwakilan).

Dalam menjalankan fungsi legislasi BPD dituntut untuk mampu menjaring aspirasi yang berkembang dimasyarakat yang memilihnya, karena apa yang akan ditetapkan dalam peraturan desa merupakan pedoman pemerintah desa dalam membuat kebijakan yang akan dilaksanakan oleh pemerintah desa maupu oleh masyarakat desa. Agar kebijakan pemerintah desa dapat berjalan sesuai dengan apa yang diharapkan, maka fungsi pengawasan atas pelaksanaan Peraturan Desa juga berada ditangan BPD, sehingga BPD harus benar-benar mengetahui apakah peraturan desa tersebut dibutuhkan atau tidak. Dalam pembuatan peraturan desa inilah letak arti pentingnya BPD, karena BPD dapat menolak dan menerima usulan rancangan peraturan desa baik yang dibuat oleh pemerintah desa maupun yang dibuat oleh anggota BPD.
BPD yang ada selama ini berubah namanya menjadi badan permusyawaratan desa perubahan ini didasarkan pada kondisi faktual bahwa budaya politik lokal yang berbasis pada filosofi "musyawarah untuk mufakat" musyawarah berbicara tentang proses sedangkan mufakat berbicara tentang hasil. Hasil yang baik diharapkan diperoleh dari proses yang baik melalui musyawarah untuk mufakat, berbagai konflik antara para elite politik dapat segera diselesaikan secara arif sehingga tidak sampai menimbulkan goncangan-goncangan yang merugikan masyarakat luas.

Dengan demikian, dengan adanya BPD diharapkan dapat membantu pemerintah desa menjadi atau membentuk pemerintahan yang baik. Namun, kurangnya sosialisasi mengenai peraturan yang telah dibuat oleh perangkat desa dan BPD yang menjadi permasalahan dalam proses penyusunan dan penetapan peraturan tidak sesuai dengan keinginan masyarakat sehingga masih banyak yang melanggar peraturan desa.

Undang-Undang Dasar Republik Indonesia 1945 Pasal 18 menentukan bahwa Pemerintah Daerah Propinsi, Daerah Kabupaten dan Kota mengatur dan mengurus sendiri urusan pemerintahan menurut asas otonomi dan tugas pembantuan. Ini artinya bahwa pemerintah daerah dapat menjalankan dan mengatur pemerintahannya tanpa campur tangan dari pemerintah pusat, kewenangan ini diberikan agar pemerintah daerah lebih dapat memperhatikan dan memajukan 
daerahnya dengan sumber pendapatan asli daerah yang dimiliki, setiap permasalahan yang terjadi didaerah dapat segera teratasi dengan adanya hak otonomi tersebut.

Secara etimologi kata desa berasal dari bahasa sansekerta, deca yang berarti tanah air, tanah asal, atau tanah kelahiran. Dari perspektif geografis, desa atau village diartikan sebagai "a groups of hauses or shops in a country area, smaller than a town". Desa adalah kesatuan masyarakat hukum yang memiliki kewenangan untuk mengurus rumah tangganya sendiri berdasarkan hak asal-usul dan adat istiadat yang diakui dalam Pemerintahan Nasional dan berada di Daerah Kabupaten.

Desa dibentuk atas prakarsa masyarakat dengan memerhatikan asal usul desa dan kondisi sosial budaya masyarakat setempat. Pembentukan desa dapat berupa penggabungan beberapa desa, atau bagian desa yang bersandingan, atau pemekaran dari satu desa menjadi dua desa atau lebih, atau pembentukan desa di luar desa yang telah ada. Desa dapat diubah atau disesuaikan statusnya menjadi kelurahan berdasarkan prakarsa pemerintah desa bersama BPD dengan memerhatikan saran dan pendapat masyarakat setempat.

Desa dalam pengertian umum adalah permukiman manusia di luar kota yang penduduknya berjiwa agraris. Dalam keseharian disebut kampung, sehingga ada istilah pulang kampung atau kampung halaman. Desa dalam definisi lainnya adalah suatu tempat atau daerah dimana penduduk berkumpul dan hidup bersama menggunakan lingkungan setempat, untuk mempertahankan, melangsungkan dan mengembangkan kehidupan mereka.

Desa yang berubah menjadi kelurahan, lurah dan perangkatnya diisi dari pegawai negeri sipil dan kekayaannya menjadi kekayaan daerah dan dikelola oleh kelurahan yang bersangkutan untuk kepentingan masyarakat setempat. Dalam wilayah desa dapat dibagi atas dusun yang merupakan bagian wilayah kerja pemerintahan desa dan ditetapkan dengan peraturan desa.

Desa bukanlah bawahan kecamatan, karena kecamatan merupakan bagian dari perangkat daerah kabupaten/kota, dan desa bukan merupakan bagian dari perangkat daerah. Pemerintahan desa terdiri atas pemerintah desa dan Badan Permusyawaratan Desa. Pemerintah desa terdiri atas Kepala Desa dan perangkat desa.

Desa menurut H.A.W. Widjaja dalam bukunya yang berjudul "Otonomi Desa" menyatakan bahwa:

Desa adalah sebagai kesatuan masyarakat hukum yang mempunyai susunan asli berdasarkan hak asal-usul yang bersifat istimewa. Landasan pemikiran dalam mengenai Pemerintahan Desa adalah keanekaragaman, partisipasi, otonomi asli, demokratisasi dan pemberdayaan masyarakat.

Desa menurut Undang-Undang Nomor 32 Tahun 2004 Tentang Pemerintahan Daerah mengartikan Desa sebagai berikut :

Desa atau yang disebut nama lain, selanjutnya disebut desa, adalah kesatuan masyarakat hukum yang 
memiliki batas-batas wilayah yang berwenang untuk mengatur dan mengurus kepentingan masyarakat setempat, berdasarkan asal-usul dan adat istiadat setempat yang diakui dan dihormati dalam sistem Pemerintah Negara Kesatuan Republik Indonesia.

Dengan dua azas utama "rekognisi" dan "subdidiaritas" Undang-Undang Desa mempunyai semangat revolusioner, berbeda dengan azas "desentralisasi" dan "residualitas". Dengan mendasarkan pada azas desentralisasi dan residualitas desa hanya menjadi bagian dari daerah, sebab desentralisasi hanya berhenti di kabupaten/kota. Disamping itu, desa hanya menerima pelimpahan sebagian kewenangan dari kabupaten/kota. Sehingga desa hanya menerima sisa-sisa lebihan daerah, baik sisa kewenangan maupun sisa keuangan dalam bentuk Alokasi Dana Desa.

Kombinasi antara azas rekognisi dan subsidiaritas Undang-Undang Desa menghasilkan definisi desa yang berbeda dengan definisi-definisi sebelumnya. Desa didefinisikan sebagai kesatuan masyarakat hukum yang memiliki batas wilayah yang berwenang untuk mengatur dan mengurus urusan pemerintahan, kepentingan masyarakat setempat berdasarkan prakarsa masyarakat, hak asal usul, dan/atau hak tradisional yang diakui dan dihormati dalam system pemerintahan NKRI.

Dengan definisi dan makna itu, Undang-Undang Desa telah menempatkan desa sebagai organisasi campuran (hybrid) antara masyarakat berpemerintahan (self governing community) dengan pemerintahan lokal (local self government). Dengan begitu, sistem pemerintahan di desa berbentuk pemerintahan masyarakat atau pemerintahan berbasis masyarakat dengan segala kewenangannya (authority). Desa juga tidak lagi identik dengan pemerintah desa dan Kepala Desa, melainkan pemerintahan desa yang sekaligus pemerintahan masyarakat yang membentuk kesatuan entitas hukum. Artinya, masyarakat juga mempunyai kewenangan dalam mengatur desa sebagaimana pemerintahan desa.

Kewenangan merupakan elemen penting sebagai hak yang dimiliki oleh sebuah desa untuk dapat mengatur rumah tangganya sendiri. Dari pemahaman ini jelas bahwa dalam membahas kewenangan tidak hanya semata-mata memperhatikan kekuasaan yang dimiliki oleh penguasa namun harus juga memperhatikan subjek yang menjalankan dan yang menerima kekuasaan. Kewenangan harus memperhatikan apakah kewenangan itu bisa diterima oleh subjek yang menjalankan atau tidak.

$$
\text { Dalam pengelompokannya, }
$$
kewenangan yang dimiliki desa meliputi; 1) kewenangan dibidang penyelenggaraan pemerintahan desa; 2) kewenangan dibidang pelaksanaan pembangunan desa; 3) kewenangan dibidang pembinaan kemasyarakatan desa; dan 4) kewenangan dibidang pemberdayaan masyarakat desa yang berdasarkan prakarsa masyarakat, atau yang berdasarkan hak asal usul dan yang berdasarkan adat istiadat desa. 
Dalam Pasal 19 dan 103 UndangUndang Desa disebutkan, Desa dan Desa Adat mempunyai empat kewenangan, meliputi; 1) Kewenangan berdasarkan hak asal usul. Hal ini bebeda dengan perUndang-Undangan sebelumnya yang menyebutkan bahwa urusan pemerintahan yang sudah ada berdasarkan hak asal usul desa; 2) Kewenangan lokal berskala Desa dimana desa mempunyai kewenangan penuh untuk mengatur dan mengurus desanya. Berbeda dengan perUndang-Undangan sebelumnya yang menyebutkan, urusan pemerintahan yang menjadi kewenangan kabupaten/ kota yang diserahkan pengaturannya kepada desa; 3) Kewenangan yang ditugaskan oleh pemerintah, pemerintah daerah provinsi, atau pemerintah daerah kabupaten/kota; 4) Kewenangan lain yang ditugaskan oleh Pemerintah, Pemerintah Daerah Provinsi, atau Pemerintah Daerah Kabupaten/Kota sesuai dengan ketentuan peraturan perundang-undangan.

Dari empat kewenangan tersebut, pada dua kewenangan pertama yaitu kewenangan asal usul dan kewenangan lokal berskala desa, terdapat beberapa prinsip penting yang dimiliki desa. Dimana kewenangan yang dimiliki oleh desa tersebut bukan-lah kewenangan sisa (residu) yang dilimpahkan oleh Pemerintah Kabupaten/Kota sebagaimana pernah diatur dalam Undang-Undang No. 32 Tahun. 2004 tentang Pemerintahan Daerah dan PP No. 72 Tahun. 2005 tentang Pemerintahan Desa. Melainkan, sesuai dengan asas rekognisi dan subsidiaritas. Dan kedua jenis kewenangan tersebut diakui dan ditetapkan langsung oleh Undang-Undang dan dijabarkan oleh Peraturan Pemerintah.

Kewenangan berdasarkan hak asal usul merupakan kewenangan warisan yang masih hidup dan atas prakarsa Desa atau prakarsa masyarakat Desa sesuai dengan perkembangan kehidupan masyarakat. Sedangkan kewenangan lokal berskala Desa merupakan kewenangan untuk mengatur dan mengurus kepentingan masyarakat Desa yang telah dijalankan oleh Desa atau mampu dan efektif dijalankan oleh Desa atau yang muncul karena perkembangan Desa dan prakasa masyarakat Desa. Kedua kewenangan ini merupakan harapan menjadikan desa berdaulat, mandiri, dan berkepribadian.

Dengan kedua kewenangan ini Desa mempunyai hak "mengatur" dan "mengurus", sebagaimana dimaksud dalam Pasal 20 Undang-Undang Desa, Desa maupun Desa Adat mempunyai kewenangan mengeluarkan dan menjalankan aturan main (peraturan), tentang apa yang boleh dan tidak boleh dilakukan, sehingga mengikat kepada pihak-pihak yang berkepentingan, dan menjalankan aturan tersebut atau bertanggung jawab merencanakan, menganggarkan dan menjalankan kegiatan pembangunan atau pelayanan, serta menyelesaikan masalah yang muncul.

Desa memiliki pemerintahan sendiri. Pemerintahan Desa terdiri atas Pemerintah Desa (yang meliputi Kepala Desa dan Perangkat Desa) dan Badan Permusyawaratan Desa (BPD). Menurut Perda Kabupaten Bogor Tahun 2006 
Tentang Desa pada pasal 13 disebutkan bahwa pemerintahan desa terdiri dari pemerintah desa dan BPD. Pemerintah desa sebagaimana dimaksud pada pasal 13 dijelaskan dalam pasal 14 ayat 1 terdiri dari Kepala Desa dan perangkat desa. Dalam ayat 2 dijelaskan perangkat desa sebagaimana dimaksud pada ayat 1 terdiri dari sekretaris desa, pelaksana teknis lapangan, dan unsur kewilayahan.

Sebagaimana telah di jelaskan dalam Peraturan Pemerintah Tahun 2005 ayat 6 yang berbunyi bahwa pemerintahan desa adalah penyelenggaran desa dalam mengatur dan mengurus kepentingan masyarakat setempat yang diakui dan dihormati dalam sistem pemerintahan NKRI.

Dan selanjutnya dinyatakan dalam ayat 7 yang berbunyi: Badan Permusyawaratan Desa atau nama lain disingkat BPD adalah lembaga yang merupakan perwujudan demokrasi dalam penyelenggaraan pemerintah Desa sebagai unsur penyelenggaraan pemerintah.pemerintah desa atau yang disebut nama lain adalah Kepala Desa dan perangkat desa sebagai unsur penyelenggaran pemerintahan desa (ayat 7).

Kepala Desa merupakan pimpinan penyelenggaraan pemerintahan desa berdasarkan kebijakan /yang ditetapkan bersama Badan Permusyawaratan Desa (BPD). Masa jabatan Kepala Desa adalah 6 tahun, dan dapat diperpanjang lagi untuk satu kali masa jabatan. Kepala Desa juga memiliki wewenang menetapkan Peraturan Desa yang telah mendapat persetujuan bersama BPD.
Dalam pembahasan mekanisme hubungan antar unsur kerja pemerintahan desa dibedakan antara hubungan unsur internal yaitu unsur aparat dan unsur eksternal (kewilayahan, organisasi dan masyarakat) dengan unsur internal.

Mekanisme hubungan kerja intern. Sebagaimana telah dijelaskan bahwa pemerintahan desa adalah pemerintah desa dan Badan Permusyawaratan Desa (BPD). Dalam pasal 200 Undang-Undang No. 32 Tahun 2004 Tentang Pemerintahan daerah ditegaskan bahwa dalam pemerintahan daerah kabupaten/kota dibentuk pemerintahan desa yang terdiri dari pemerintah desa dan Badan Permusyawaratan Desa (BPD). Pengertian tersebut mengandung arti bahwa antara pemerintah desa dan BPD mempunyai kedudukan sejajar dan bermitra, maka harus dapat bekerjasama dan sinergis dalam mencapai tujuan pemerintahan desa yaitu untuk mensejahterakan masyarakat desa.

Dalam kemitraan antara legislatif (BPD) dengan eksekutif (pemerintah desa) menurut Sadu Wasistiono menyatakan:

Didasarkan pada budaya politik lokal yang berbasis pada filosofi musyawarah mufakat, musyawarah berbicara tentang proses sedangkan mufakat berbicara tentang hasil. Hasil yang baik diharapkan dari proses yang baik. Melalui musyawarah untuk mufakat berbagai konflik antara para elite politik segera diselesaikan secara arif sehingga tidak menimbulkan goncangan- 
goncangan yang merugikan masyarakat luas.

Adapun hubungan kemitraan antara pemerintah desa dengan BPD diwujudkan dalam bentuk pembuatan peraturan desa, pengawasan dan pertanggungjawaban Kepala Desa.

Mekanisme hubungan unsur eksternal dengan unsur internal. Dalam membahas mekanisme hubungan antara unsur pemerintahan desa maka akan dijelaskan keterkaitan antar komponen yang ada dalam penyelenggaraan pemerintahan desa yaitu unsur kewilayahan-unsur organisasi, unsur aparat dan unsur masyarakat, yang dilayani sebagai berikut: 1) Wilayah dan masyarakat merupakan unsur potensi yang merupakan obyek sekaligus merupakan subyek penyelenggaraan pemerintahan, oleh karena itu harus dikelola dan diberdayakan sedemikian rupa oleh unsur aparat yang diwadahi oleh suatu organisasi pemerintahan dan pemerintahan desa; 2) Bentuk sebutan organisasi pemerintahan desa harus disesuaikan dengan adat istiadat setempat sehingga dikenal oleh masyarakat, dalam mengambil kebijakan di segala pemerintahan, pembangunan dan pembinaan masyarakat harus melibatkan unsur masyarakat sebagai pengguna dan pelaksana; 3) Aparat desa sebagai aparat yang dipercaya oleh masyarakat hendaknya dalam bekerja dalam mengelola sumber daya yang ada di wilayahnya dengan memperhatikan dan memanfaatkan kondisi wilayah secara optimal dan maksimal dengan sebayak mungkin melibatkan partisipasi masyarakat dalam pengambilan kebijakan maupun dalam pelaksanaannya.

Pasal 69 Undang-Undang Desa menjelaskan, regulasi di Desa meliputi: Peraturan Desa, Peraturan Bersama Kepala Desa dan Peraturan Kepala Desa. Dan peraturan-peraturan tersebut ditetapkan oleh Kepala Desa setelah dibahas dan disepakati bersama BPD sebagai sebuah kerangka hukum dan kebijakan dalam penyelenggaraan pemerintahan desa dan pembangunan desa.

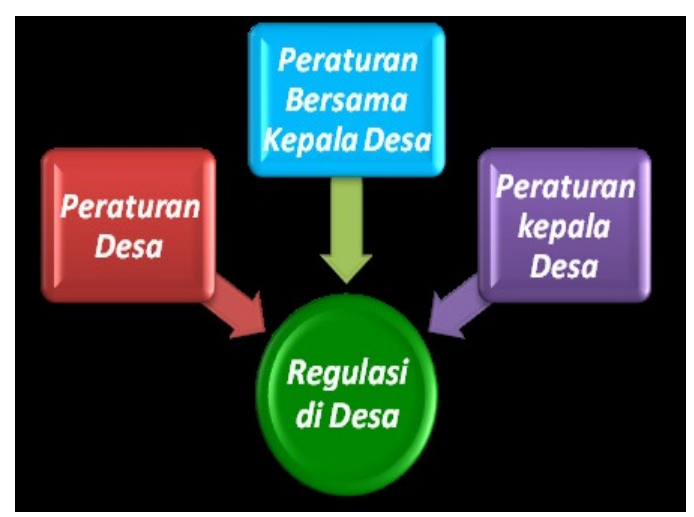

Gambar 1. Regulasi di Desa

Peraturan desa adalah peraturan perundang-undangan yang ditetapkan oleh kepala desa setelah dibahas dan disepakati bersama BPD (Undang-Undang RI No. 6 Tahun 2014 Tentang Desa bab I, pasal I ayat 7). Peraturan desa dibentuk dalam rangka penyelenggaraan pemerintahan desa dengan demikian maka pemerintahan desa harus merupakan penjabaran lebih lanjut dari peraturan perUndang-Undangan yang lebih tinggi dan tidak boleh bertentangan dengan kepentingan umum. Dan atau peraturan perUndang-Undangan yang lebih tinggi serta harus memperhatikan 
kondisi sosial budaya masyarakat desa setempat dalam upaya mencapai tujuan pemerintahan, pembagunan dan pelayanan masyrakat jangka panjang, menengah dan jangka pendek.

Peraturan desa merupakan penjabaran lebih lanjut dari peraturan perUndangUndangan dengan memperhatikan kondisi sosial masyarakat setempat. Peraturan desa dilarang bertentangan dengan kepentingan Dan atau peraturan perUndang-Undangan yang lebih tinggi. secara teoritis, pembuatan produk hukum harus didasari oleh paling tidak empat dasar pemikiran antara lain:

1. Dasar Filosofis, merupakan dasar filsafat atau pandangan hidup yang mejadi dasar cita-cita sewaktu menuangkan hasrat kedalam suatu rancangan/draft, peraturan perUndang-Undangan sehingga hukum yang dibentuk tidak bertentangan dengan nilai-nilai moral atau nilai-nilai adat yang dijunjung tinggi masyarakat. Menurut Satdjpto Rahardjo, asas hukum ini juga lazim disebut sebagai dasar atau alasan bagi lahirnya suatu peraturan hukum atau merupakan ratio legis dari peraturan hukum.

2. Landasan sosiologis, bahwa peraturan perUndang-Undangan yang dibuat harus dipahami oleh masyarakat dan harus sesuai dengan kenyatan hidup masyrakat yang bersangkutan. Aturan hidup yang dibuat harus sesuai dengan kebutuhan, keyakinan dan kesdaran masyarakat.

3. Landasan yuridis, bahwa yang menjadi landasan dalam pembuatan peraturan perUndang-Undangan adalah peraturan atau sederet peraturan perUndang-Undangan yang lebih tinggi dan dasar kewenangan seorang pejabat atau badan membentuk peraturan perUndangUndangan.

4. Dasar hukum, tolak ukur diatas dapat memberikan jaminan bahwa rancangan peraturan perUndangUndangan yang dibuat merupakan cikal bakal peraturan perUndangUndangan yang diterima oleh masyarakat (acceptable), populis dan efektif. Populis karena mengakomodir sebanyak-banyaknya keinginan penduduk di daerah. Efektif karena peraturan yang dibuat itu operasional, dan jangkauan peraturannya mencakup sebanyak-banyaknya kepentingan masyarakat dan senantiasa sesuai dengan tuntutan perkembangan zaman. Sehingga setiap kebutuhan masyarakat pada setiap era mampu diwadahinya.

Peraturan desa yang wajib dibentuk berdasaarkan Peraturan Pemerintah No. 72 Tahun 2005 Tentang Desa adalah sebagai berikut:

1. Peraturan desa tentang susunan organisasi dan tata kerja pemerintahan desa (pasal 12 ayat 5)

2. Peraturan desa tentang Anggaran pendapatan dan Belanja Desa (pasal 73 ayat 3 )

3. Peraturan desa tentang rancangan pembangunan jangka menengah desa (RPJMD) (pasal 64 ayat 2)

4. Peraturan desa tentang pengelolaan keuangan desa (pasal 76) 
5. Peraturan desa tenang pembentukan Badan Usaha Milik Desa (pasal 78 ayat 2), apabila pemerintahan Desa membentuk BUMD

6. Peraturan desa tentang pembentukan Badan Kerjasama (pasal 82 ayat 2)

7. Peraturan desa tentang Lembaga /kemasyaraatan (pasal 89 ayat 2).

Selain peraturan desa yang wajib dibentuk seperti tersebut diatas, pemerintah desa juga dapat membentuk peraturan desa yang merupakan plelaksanaan lebih lanjut dari peraturan daerah dan peraturan perUndangUndangan lainnya dengan kondisi sosial budaya setempat antara lain:

1. Peraturan desa tentang pembentukan panitia pencalonan dan pemilihan kepala desa

2. Peraturan desa tentang penetapan yang berhak menggunakan hak pilih dalam pemilihan kepala desa

3. Peraturan desa tentang penentuan tanda gambar calon, pelaksanaan kampanye cara pemilihan dan biaya pelaksanaan pemilihan kepala desa

4. Peraturan desa tentang pemberian penghargaan kepada mantan kepala desa dan perangkat desa

5. Peraturan desa tentang penetapan pengelolaan dan pengaturan pelimpahan/pelimpahan fungsi sumber-sumber pendapatan dan kekayaan desa.

6. Peraturan desa tentang pungutan desa.

Selain hal diatas perlu juga diperhatikan bahwa dalam hal pembahasan rancangan peraturan desa masyarakat berhak memberikan masukan baik secara lisan maupun tertulis (pasal 83 ayat (3) PP RI Nomor 43 Tahun 2014 Tentang Peraturan Pelaksanaan UndangUndang Nomor 6 Tahun 2014 Tentang Desa dan peraturan desa disampaikan oleh Kepala desa kepada bupati/ walikota melalui camat sebagai bahan pengawasan dan pembinaan paling lambat tujuh hari setelah ditetapkan (pasal 84 ayat (4) PP RI No. 43 Tahun 2014).

Secara umum proses pembuatan peraturan desa melalui tiga tahapan yakni:

\section{a. Tahap Inisiasi}

Pada tahap inisiasi ide atau gagasan dalam pembuatan peraturan desa dapat datang dari dua belah pihak baik dari pemerintah desa maupun dari BPD. Apabila usulan tersebut datangnya dari BPD, maka rancangan tersebut diserahkan kepada kepala desa, begitupun juga sebaliknya apabila usulan tersebut datangnya dari kepala desa maka rancangan peraturan desa diserahkan kepada BPD artinya keduanya mempunyai hak untuk mengajukan peraturan desa.

BPD mengadakan rapat yang dihadiri oleh ketua-ketua bidang (bidang kemasyarakatan atau pemerintahan dan pembangunan) untuk membahas usulan tersebut apabila disepakati perlu adanya peraturan desa sesuai dengan usulan tersebut maka hasil rapat tersebut dijadikan pra-rancangan peraturan desa.

Usulan peraturan desa juga dapat dari masukan anggota masyarakat yang secara langsung atau lewat BPD kemudian dari BPD lalu dibahas semacam kepanitiaan kecil, bila disetujui barulah rapat secara lengkap untuk membahas pantas tidaknya 
peraturan desa setelah itu dibuat rancangan peraturan desa. Sebuah ide atau gagasan pembuatan peraturan desa harus dibahas terlebih dahulu melalui sidang pleno guna menetapkan apakah usulan tersebut disetujui menjadi sebuah rancangan peraturan desa atau tidak. Setelah mendapat persetujuan dari rapat BPD bahwa dari usulan pembuatan peraturan desa menjadi rancangan peraturan desa, maka sekretaris BPD membuat rancangan peraturan desa untuk diserahkan kepada kepala desa dalam bentuk tulisan guna mendapat persetujuan untuk menjadi peraturan desa. Setelah kepala desa menerima rancangan peraturan desa, kepala desa mengadakan rapat bersama dengan perangkatnya guna membahas rancangan yang disampaikan oleh BPD. Hasil keputusan rapat tersebut akan dibahas dalam rapat gabungan yang dihadiri oleh BPD, kepala desa dan perangkatnya sebagaimana diketahui bahwa yang dimaksud dengan perangkat desa sesuai dalam pasal 61 ayat (1) Peraturan Pemerintah Nomor 43 tahun 2014 tentang perangkat desa terdiri dari sekretariat desa, pelaksana kewilayahan dan pelaksana teknis.

Berdasarkan Peraturan Menteri Dalam Negeri No. 29 Tahun 2006 Tentang Pedoman Pembentukan dan Mekanisme Penyusunan Peraturan desa pasal 10 ayat (1-3), Rancangan Peraturan Desa tentang Anggaran Pendapatan dan Belanja Desa, pungutan, dan penataan ruang yang telah disetujui bersama dengan BPD, sebelum ditetapkan oleh Kepala Desa paling lama 3 (tiga) hari disampaikan oleh Kepala Desa kepada Bupati/Walikota untuk dievaluasi. Hasil evaluasi rancangan Peraturan Desa sebagaimana dimaksud diatas disampaikan oleh Bupati/Walikota kepada kepala desa paling lama 20 (dua puluh) hari sejak rancangan peraturan desa tersebut diterima. Apabila bupati/walikota belum memberikan hasil evaluasi rancangan anggaran pendapatan dan belanja desa paling lama 20 (dua puluh) hari sejak rancangan peraturan desa tersebut diterima, maka kepala desa dapat menetapkan rancangan peraturan desa tentang anggaran pendapatan dan belanja desa (APBDesa) menjadi peraturan desa. Kemudian pada pasal 11 Peraturan Menteri Dalam Negeri No. 29 Tahun 2006 Tentang Pedoman pembentukan dan Mekanisme penyusunan Peraturan Desa dijelaskan bahwa evaluasi rancangan peraturan desa tentang anggaran pendapatan dan belanja desa sebagaimana dimaksud dalam pasal 10 dapat didelegasikan kepada Camat.

\section{b. Tahap Sosio Politis}

Rancangan Peraturan Desa yang telah diterima oleh pemerintah Desa, diadakan pembahasan dalam rapat gabungan antara BPD, Kepala Desa serta perangkat desa. Peranan perangkat desa tersebut dimaksudkan untuk menampung aspirasi masyarakat sehingga dalam pelaksanaannya nanti perdes dapat diterima. Dalam rapat pembahasan ketua BPD memberikan penjelasan mengenai latar belakang dan tujuan dibuatnya perdes. Selanjutnya dalam rapat tersebut diadakan sesi Tanya jawab sebagai bagian pengumpulan aspirasi. Kemudian Kepala 
Desa diberi draft RAPERDES sebelum diadakan rapat pembahasan. Pada waktu rapat pembahasan, permasalahan yang ada dalam RAPERDES dibahas satu persatu, dibacakan oleh ketua BPD, dan yang menetapkan perdes adalah Kepala Desa.

RAPERDES yang diajukan bermula dari satu pendapat atau satu pandangan baik dari pihak BPD atau pihak Kepala Desa, setelah dibahas bertemu dengan Kepala Desa, sekretaris desa, dan perangkat desa lainnya sehingga mengalami perubahan yang bertujuan untuk menyempurnakan isi dan materi perdes, sehingga perdes yang dihasilkan dapat memenuhi aspirasi masyarakat dan menyangkut kepentingan umum. Setelah diadakan pembahasan yang mendalam maka dapat diambil sebuah keputusan dapat diterima atau tidaknya rancangan tersebut menjadi sebuah perdes. Pengambilan keputusan tentang peraturan desa biasanya dilakukan dengan musyawarah untuk mufakat. Namun tidak menutup kemungkinan diadakan voting.

\section{c. Tahap Yuridis}

Setelah rancangan tersebut mendapat persetujuan dari semua pihak untuk dijadikan peraturan desa maka langkah selanjutnya adalah kepala desa bersama BPD menetapkan rancangan peraturan desa tersebut menjadi sebuah peraturan desa sesuai Pasal 83 ayat (4) Peraturan Pemerintah RI Nomor 43 Tahun 2014 Tentang Desa. Namun sebelumnya, rancangan peraturan desa yang telah disetujui bersama kepala desa dan BPD tersebut disampaikan oleh pimpinan BPD kepada kepala desa, penyampaian rancangan peraturan desa dilakukan dalam jangka waktu paling lambat 7 (tujuh) hari terhitung sejak tanggal persetujuan bersama (Peraturan Pemerintah RI No. 43 Tahun 2014 pasal 84 ayat 1$)$.

Setelah aspek-aspek diatas telah terpenuhi, maka pembuatan kebijakan desa dpat dikatakan sudah berjalan sesuai prosedur tanpa ada pihak-pihak terkait yang tidak terakomodir.

Penyusunan regulasi yang aspiratif dan partisipatif hendaknya mencerminkan komitmen bersama antara Kepala Desa (Kades), Badan Permusyawaratan Desa (BPD) dan masyarakat desa. Komitmen bersama ini diharapkan jadi proses demokratisasi yang baik dalam kehidupan bermasyarakat. Apalagi masyarakat desa sudah diberi wewenang oleh pemerintah untuk mengatur dirinya sendiri, yaitu melalui Perdes yang bertujuan meningkatkan kesejahteraan masyarakat.

Demi mendapatkan regulasi desa yang efektif, maka hal itu dilakukan melalui Musyawarah Desa (yang selanjutnya disebut Musdes) sebagai sistem baru dan tatanan baru bagi desa pengejawantahan dari sistem demokrasi partisipatoris dan permusyawaratan sebagaimana dijelaskan dalam Permendesa PDTT No. 2 Tahun 2015 Tentang Pedoman Tata Tertib Dan Mekanisme Pengambilan Keputusan Musyawarah Desa.

Musdes merupakan forum musyawarah antara BPD, Pemerintah Desa, dan unsur masyarakat yang diselenggarakan oleh Badan Permusyawaratan Desa untuk menyepakati hal yang bersifat strategis, 
bisa terkait tentang penataan Desa, perencanaan Desa, rencana investasi yang masuk ke Desa, pembentukan BUM Desa, dan beberapa yang lainnya dengan prinsip partisipatif, demokratis, dan transparan.

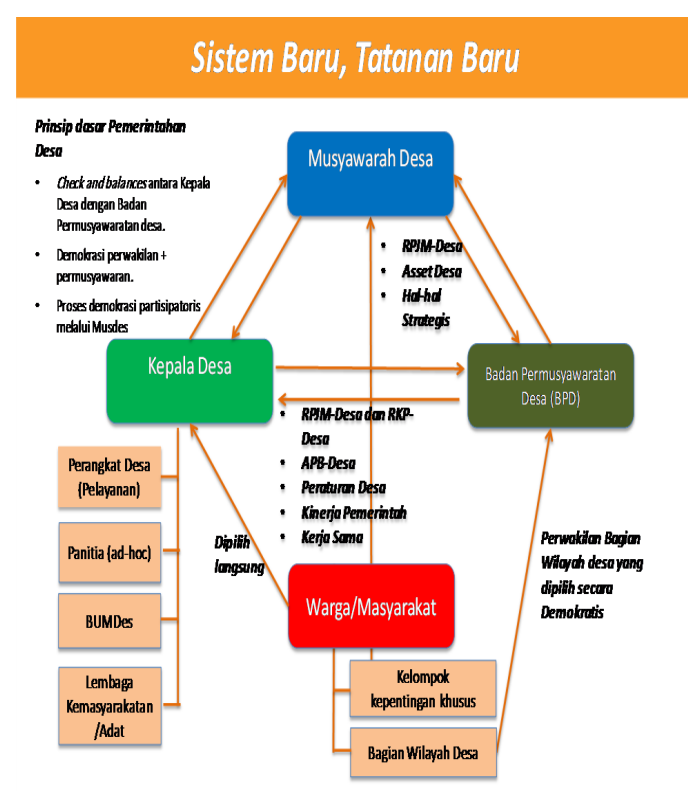

Gambar 2. Sistem Baru, Tatanan Baru

Musyawarah Desa (Musdes) adalah proses musyawarah antara Badan Permusyawaratan Desa (BPD), Pemerintah Desa, dan unsur masyarakat yang diselenggarakan oleh BPD untuk menyepakati hal yang bersifat strategis. Musyawarah adalah forum pengambilan keputusan yang sudah dikenal sejak lama dan menjadi bagian dari dasar negara. Sila keempat Pancasila menyebutkan kerakyatan yang dipimpin oleh hikmat kebijaksanaan dalam permusyawaratan/perwakilan.

Penjelasan Umum Undnag-Undang Desa juga memuat penjelasan mengenai Musdes. Selengkapnya disebutkan:

Musyawarah Desa atau yang disebut dengan nama lain adalah forum musyawarah antara Badan Permusyawaratan Desa, Pemerintah Desa, dan unsur masyarakat yang diselenggarakan oleh Badan Permusyawaratan Desa untuk memusyawarahkan dan menyepakati hal strategis dalam penyelenggaraan pemerintahan Desa. Hasil musyawarah desa dalam bentuk kesepakatan dituangkan dalam keputusan hasil musyawarah dijadikan dasar oleh Badan Permusyawaratan Desa dan Pemerintah Desa untuk menetapkan kebijakan Pemerintahan Desa.

Berdasarakan uraian diatas penulis merasa tertarik untuk meneliti bagaimana proses BPD dalam melakukan penyusunan dan penetapan peraturan desa dihubungkan dengan Undang-Undang No. 6 Tahun 2014 tentang Desa.

\section{METODE PENELITIAN}

Penelitian ini merupakan field research dengan mengambil data menggunakan wawancara dan studi dokumen yang dianalisis secara deskriptif. Adapun tempat penelitiannya yaitu di Desa Tegal Kecamatan Kemang Kabupaten Bogor.

Sumber data didapatkan melalui field research, dengan mendatangi sumber data yang relevan yaitu kantor Desa Tegal Kecamatan Kemang Kabupaten Bogor. Selain itu sumber data juga diperoleh dari penelitian pustakawan yang berhubungan dengan permasalahan yang terdiri dari bahan hukum primer yang berasal dari peraturan perundang-undangan seperti Undang-Undang 1945, Undang-Undang 
Nomor 6 Tahun 2014 tentang Desa serta bahan hukum sekunder yang menjelaskan tentang hukum primer berupa buku-buku, majalah, makalah artikel dan sumbersumber lainnya.

\section{HASIL DAN PEMBAHASAN}

Peraturan Pemerintah No. 43 tahun 2014 Tentang Desa menegaskan bahwa ada beberapa peraturan desa yang wajib dibentuk atau dibuat oleh pemerintah desa di Indonesia, salah satunya yakni Peraturan Desa Tentang Anggaran Pendapatan dan Belanja Desa (APBDesa). Berdasarkan peraturan perUndangUndangan tersebut Kepala Desa dan BPD Desa Tegal secara bersama-sama membuat Peraturan Desa Tegal No. 02 tahun 2016 tentang Anggaran Pendapatan dan Belanja Desa (APBDesa) tahun 2016. Peraturan desa tersebut merupakan pedoman sekaligus landasan dalam pembuatan Rencana Anggaran Pendapatan dan Belanja Desa (APBDesa) tahun 2016. Dalam pembuatannya, peraturan desa tersebut telah melewati proses yang panjang hingga dapat menjadi sebuah peraturan yang dapat diberlakukan di Desa Tegal.

Sesuai yang dikemukakan pada bab sebelumnya, dalam proses pembuatan peraturan desa dapat dibagi menjadi 3 (tiga) tahap yakni tahap inisiasi, tahap sosio-politis dan tahap yuridis. Tahaptahap tersebut menjadi pedoman dalam pembuatan peraturan desa tidak terkecuali dalam pembuatan Peraturan Desa Tegal No. 02 tahun 2016 tentang Anggaran Pendapatan dan Belanja Desa
(APBD) tahun 2016. Dalam pembuatan peraturan desa tersebut melibatkan banyak pihak. Namun, dalam pembuatan peraturan desa tersebut didominasi oleh Pemerintah Desa Tegal.

BPD Desa Tegal yang merupakan lembaga legislasi di Desa Tegal tentunya memiliki peran-peran tersendiri. Peranperan tersebut sangat erat kaitannya dalam proses pembuatan peraturan desa khususnya dalam pembuatan Peraturan Desa Tegal No. 02 tahun 2016 Tentang APBDesa Tahun 2016 di Desa Tegal. BPD Desa Tegal dituntut melaksanakan fungsi legislasinya semaksimal mungkin dalam pembuatan peraturan desa tersebut. Oleh karena itu, dalam bab ini penulis akan mengulas bagaimana pelaksanaan fungsi legislasi Badan Permusyawaratan Desa Tegal dalam Tahap Inisiasi, Sosio-politis dan Yuridis pembuatan Peraturan Desa Tegal No. 1 tahun 2016 Tentang APBDesa Tahun 2016.

\section{Tahap Inisiasi}

Tahap Inisiasi pembuatan Peraturan Desa Tegal No. 02 tahun 2016 Tentang APBDesa Tahun 2016 merupakan tahap munculnya gagasan oleh Pemerintah Desa Tegal. Dalam pembentukan peraturan desa tersebut, tahapan ini adalah tahapan yang paling awal. Dalam Tahap Inisiasi ini, BPD Desa Tegal tidak memiliki hak untuk mengajukan usulan rancangan peraturan desa. Hal tersebut sesuai dengan Permendagri No.111 Tahun 2014 pasal 7 (2), namun hak untuk mengajukan usulan rancangan peraturan Desa tentang APBDesa yaitu Pemerintah Desa. 
Pemerintah Desa Tegal berasumsi bahwa pada saat itu Desa Tegal memang sangat membutuhkan peraturan desa tentang APBDesa, untuk membenahi Desa Tegal dalam hal pembenahan infrastruktur dan suprastrukur Desa Tegal. Hal tersebut diungkapkan oleh Elismayanti S.Sos selaku Kepala Desa Tegal, berikut pernyataannya:

Dalam pembenahan desa Tegal peraturan desa tentang APBDesa sangat dibutuhkan, karena untuk menciptakan infrastruktur dan suprastuktur yang memadai dibutuhkan aturan, apalagi sudah keharusan desa harus memiliki peraturan desa tentang anggaran pendapatan dan belanja desa, atas dasar itulah kami sebagai Pemerintah Desa Tegal mengusulkan rancangan peraturan desa tentang APBDesa kepada BPD Desa Tegal untuk di tindak lanjuti (wawancara pada tanggal 10 februari 2017).

Berdasarkan dari uraian serta penyataan di atas yang dikemukakan oleh salah satu informan dalam penelitian, di dapat alasan mengapa Pemerintah Desa Tegal melakukan pengusulan dalam pembentukan Peraturan Desa Tegal No. 1 tahun 2015 Tentang APBDesa Tahun 2015 antara lain:

1. Menjalankan amanah Peraturan Pemerintah No. 43 tahun 2014 yang mengharuskan pembuatan peraturan desa tentang Anggaran Pendapatan Dan Belanja Desa

2. Desa Tegal sangat membutuhkan peraturan desa tersebut dalam membenahi Desa Tegal
3. Dalam pembenahan infrastruktur dan suprastruktur harus dilandasi dengan peraturan desa

Dalam Tahap Inisiasi pembuatan Peraturan Desa Tegal No. 02 tahun 2016 Tentang APBDesa Tahun 2016 diawali dengan pengumpulan aspirasi masyarakat. Pengumpulan aspirasi ini dilakukan dalam bentuk musyawarah. Musyawarah tersebut dilakukan di tingkat RT dan dusun di Desa Tegal. Setelah aspirasi masyarakat telah dikumpulkan, proses atau langkah selanjutnya adalah melakukan penyusunan dan pengusulan.

Penyusunan dan pengusulan dilakukan dalam rapat yang dilaksanakan oleh Pemerintah Desa Tegal, rapat ini bersifat internal. Hasil dari rapat internal yang dilakukan pemerintah Desa kemudian di konsultasikan kepada camat kecamatan Kemang bersama dengan tokoh masyarakat yang berada Desa Tegal, selain menyusun dan mengusulkan rancangan peraturan desa, Pemerintah Desa juga melibatkan BPD Desa Tegal dalam proses penetapan rancangan peraturan desa yang akan diajukan selanjutnya.

Berdasarkan uraian di atas, tahap inisiasi pembuatan Peraturan Desa Tegal Kecamatan Kemang Kabupaten Bogor No. 02 tahun 2016 Tentang APBDesa Tahun 2016 dapat dibagi menjadi 3 subtahap.

Sebelum pemerintah Desa Tegal melakukan Pengusulan dan Penyusunan Rancangan Peraturan Desa tentang APBDesa tahun 2016 Yang ditetepkan menjadi rancangan peraturan desa oleh BPD dan pemerintah desa Tegal, ada proses yang turut berperan dalam inisiasi 
yang dilakukan oleh Pemerintah Desa Tegal. Proses tersebut adalah pengumpulan aspirasi masyarakat. Pengumpulan aspirasi tersebut terbagi atas musyawarah RT dan musyawarah dusun. Musyawarah RT dan dusun tersebut merupakan media bagi Pemerintah Desa dalam mengumpulkan aspirasi masyarakat Desa Tegal merupakan wadah bagi masyarakat Desa Tegal dalam menyalurkan aspirasinya khususnya dalam proses pembuatan Peraturan Desa Tegal No. 02 tahun 2016 Tentang APBDesa Tahun 2016. Hal ini didukung oleh keterangan dari salah seorang dari tokoh masyarakat sekaligus salah seorang kepala dusun di Desa Tegal berikut ini.

\begin{tabular}{lrr}
$\begin{array}{l}\text { Sebelum Pemerintah Desa Tegal } \\
\text { merumuskan }\end{array}$ & $\begin{array}{r}\text { ranperdes, } \\
\text { Pemerintah Desa }\end{array}$ \\
mengumpulkan & \multicolumn{3}{r}{ aspirasi } \\
masyarakat yang dihasilkan dalam \\
musyawarah RT dan dusun. Saya \\
bersama kepala-kepala & dusun \\
lainnya memberikan & hasil \\
musyawarah dusun & ke \\
Pemerintah & Desa & untuk \\
dikumpulkan dan diajukan secara \\
resmi untuk kemudian dibahas \\
secara bersama oleh Pemerintah \\
desa Tegal Dan Camat Kecamatan \\
Kemang (Wawancara dengan M. \\
Jaenudin tanggal 10 & februari \\
2017).
\end{tabular}

Pengumpulan aspirasi oleh Pemerintah Desa Tegal didasarkan pada Peraturan Menteri Dalam Negri No. 111 tahun 2014 bahwa Pemerintah Desa memiliki fungsi dan wewenang dalam menampung aspirasi masyarakat, sehingga dapat diartikan bahwa Pemerintah Desa sebagai penyelenggaraan pemerintahan desa untuk melakukan upaya untuk menggalang aspirasi masyarakat. Oleh karena itu, Pemerintah Desa Tegal berinisiatif untuk meminta kepada aparat pemerintah dusun dan RT untuk mengumpulkan masyarakatnya dalam forum musyawarah. Pengumpulan hasil dari musyawarah RT dan dusun tersebut akan dikonsultasikan kepada Camat Kecamatan Kemang sebagai bahan pertimbangan dalam merumuskan rancangan peraturan desa tentang APBDesa tahun 2016, dan proses selanjutnya pemerintah desa membahas rancangan peraturan desa untuk di tetapkan menjadi rancangan peraturan APBDesa bersama BPD Desa Tegal.

Pengumpulan aspirasi masyarakat dalam proses pembuatan peraturan desa memiliki peranan tersendiri dalam pelaksanaan Tahap Inisiasi, yaitu sebagai berikut; 1) Merupakan proses yang bersifat penunjang dalam menciptakan peraturan desa yang berpihak kepada masyarakat desa; 2) Merupakan proses persiapan dalam melakukan perumusan rancangan peraturan desa; dan 3) Mendorong tercapainya tingkat keefektifan dan efisiensi dalam pembuatan sebuah peraturan desa.

Peran Pemerintah Desa Tegal dalam proses pengumpulan aspirasi masyarakat terkaitan penyusunan dan penetapan peraturan desa.

Pemerintah Desa Tegal memiliki peran dalam menggagas terciptanya proses Pengumpulan Aspirasi Masyarakat 
sebagai proses sebelum atau Prapembuatan peraturan desa termasuk dalam pembuatan Peraturan Desa Tegal No. 02 Tahun 2016 Tentang APBDesa Tahun 2016. Pemerintah Desa Tegal menghimbau kepada aparat pemerintah tingkat RT dan Dusun dengan meminta aparat pemerintah tingkat RT dan dusun mengumpulkan masyarakat di RT dan Dusun masing-masing untuk kemudian dilakukan musyawarah. Pemerintah Desa Tegal terlibat langsung dalam musyawarah tersebut. Pemerintah Desa Tegal menggagas dan melasaksanakan musyawarah tersebut untuk dijadikan bahan pertimbangan pemerintah Desa Tegal dalam merumuskan rancangan peraturan desa yang akan di konsutrasikan Bersama Camat Kecamatan Kemang.

Berdasarkan penjelasan di atas, Peran Pemerintah Desa Tegal Dalam proses Pengumpulan Aspirasi Masyarakat di Desa Tegal adalah sebagai berikut; 1) Sebagai penggagas dan Pelaksana terciptanya proses Pengumpulan aspirasi masyarakat dalam pembuatan peraturan APBDesa di Desa Tegal; dan 2) Menghimpun hasil dari musyawarah untuk menjadi bahan pertimbangan Pemerintah dalam merumuskan rancangan peraturan desa yang akan di konsultasikan Bersama Camat Kecamatan Kemang.

Proses Perumusan dalam pembuatan peraturan Desa Tegal

Dalam Tahap Inisiasi pembentukan Peraturan Desa Tegal No. 02 tahun 2016 tentang APBDesa, Perumusan menjadi kelanjutan dari proses pengumpulan aspirasi masyarakat. Proses Perumusan ini memiliki peranan yang sangat vital dalam pembentukan Peraturan Desa Tegal No. 02 tahun 2016 tentang APBDesa tahun 2016 karena dalam proses ini membutuhkan ketelitian, ketepatan dan kemampuan dari Pemerintah Desa Tegal untuk menerjemahkan kondisi kekinian Desa Tegal. Dengan memenuhi hal tersebut, peraturan desa yang dibuat akan sesuai dengan kebutuhan masyarakat Desa Tegal. Dalam Proses perumusan ini, hasil pengumpulan aspirasi masyarakat yang telah dilakukan sebelumnya akan disimpulkan. Penarikan kesimpulan ini dilakukan dalam forum rapat yakni Rapat Pemerintah Desa Tegal dan di konsultasikan Bersama camat Kecamatan Kemang

\section{Rapat Gabungan pemerintah Desa Tegal}

Dalam pembuatan Rancangan Peraturan Desa Tentang APBDesa Tahun 2016 dilakukan oleh pemerintah Desa Tegal. Pembuatan Rancangan dilakukan dalam rapat Pemerintah Desa Tegal yang Bersifat Rapat Gabungan. Rapat dilaksanakan pada 10 Januari 2016. Rapat ini dihadiri oleh Elismayanti S.Sos, selaku kepala Desa Tegal, Muhtadin selaku sekretaris Desa Tegal, Asep, Linda, Dede dan Ade sebagai anggota Pemerintah desa Tegal, ahmad Saroh selaku ketua BPD, Aping /apendi selaku sekertaris BPD, Omat, Sukanta, Ronah selaku anggota BPD. dalam rapat ini dalam rapat ini juga juga turut hadir para kepala dusun di Desa Tegal, Dadi, Mulyadi dan jaenudin yang menjadi tamu undangan guna 
diminta penjelasannya yang berkaitan dengan hasil musyawarah dusun. Adapun absensi rapat gabungan yang di lakukan Oleh Pemerintah desa dapat di lihat pada tabel berikut:

Tabel 1. Absensi Rapat Gabungan Desa Tegal

\begin{tabular}{ll}
\hline Absensi & $\begin{array}{l}\text { Peranan Dalam } \\
\text { Rapat }\end{array}$ \\
\hline Elismayanti, S.Sos & Pimpinan Rapat \\
Isra Trisanti & Notulis \\
Omat Jayadihati, & Perserta Rapat \\
S.Sos & \\
Ahmad Saroh & Peserta Rapat \\
Aping Apendi & Peserta Rapat \\
Mad Roí & Peserta Rapat \\
Ronah & Peserta Rapat \\
Kamsa Sukanta & Peserta Rapat \\
\hline
\end{tabular}

Rapat BPD terkait perumusan Rancangan Peraturan Desa Tentang APBDesa Tahun 2016 diadakan di Kantor Desa Tegal. Rapat ini bertujuan untuk membahas usulan dari musyawah dusun yang telah diterima Pemerintah Desa. Rapat ini dipimpin dan dibuka langsung oleh Elismayanti, S.Sos sebagai Kepala Desa Tegal. Pimpinan Rapat kemudian memaparkan hasil musyawarah dusun kepada peserta rapat karena sebelumnya Kepala Desa Tegal telah menerima hasil dari musyawarah dusun. Setelah semuanya telah selesai dipaparkan oleh pimpinan rapat kemudian oleh pimpinan rapat meminta tanggapan berupa kritik dan saran dari peserta rapat berkaitan dengan hasil musyawarah dusun yang telah dipaparkan.
Setelah mendengar masukan-masukan yang di terima oleh pemerintah desa. Proses selanjutnya Pemerintah Desa beserta BPD Desa Tegal menetapkan Rancangan Peraturan Desa Tentang APBDesa Tahun 2016. Dalam rapat Pemerintah Desa ini, rumusan yang telah di tetapkan menjadi ranperdes yang akan diajukan secara resmi. Rapat ini berlangsung selama kurang lebih 2 jam, mulai dari pukul 15.00 Wib sampai pukul 17.15 Wib.

Penetapan rancangan peraturan desa yang melibatkan BPD Desa Tegal.

Dalam proses Penetapan Ranperdes tentang APBDesa no 02 tahun 2016, peran BPD Desa Tegal jelas terlihat pada proses Rapat gabungan yang di selanggarakan oleh Pemerintah desa Tegal. Dalam Rapat Gabungan tersebut, BPD mempunyai peranan memberikan masukan-masukan serta menetapan rancangan peraturan desa bersama pemerintah desa tentang APBDesa no 2 tahun 2016 untuk selanjutnya di bawa ketahapan sosio-politis, yaitu pembahasan rancangan peraturan APBDesa menjadi Peraturan APBDesa yang nantinya akan di sahkan menjadi peraturan desa. peran BPD Desa Tegal dalam proses Penetapan rancangan peraturan desa adalah sebagai berikut; 1) BPD dapat memberikan masukan-masukan mengeni rancangan peraturan desa; dan 2) BPD bersama pemerinta Desa Tegal menetapkan Ranperdes yang akan di bahas di tahap selanjutnya. 


\section{Tahap Sosio Politis}

Tahap sosio-politis merupakan kontinuitas/kelanjutan dari Tahap Inisiasi karena berperan sebagai tahap kedua dalam proses pembuatan Peraturan Desa Tegal No. 2 Tahun 2016 Tentang APBDesa Tahun 2016 setelah Tahap Inisiasi. Tahap Sosio-politis merupakan tahap lanjutan dari tahap inisiasi sebelumnya. Tahap ini dapat dikatakan sebagai penentu kualitas dari Peraturan Desa Tegal No. 1 Tahun 2015 Tentang APBDesa Tahun 2015 yang akan dihasilkan nantinya. Peraturan desa akan memiliki kualitas sebagai peraturan perUndang-Undangan jika isi dari peraturan desa tersebut memiliki ketepatan dan kesesuaian antara aturan yang dihasilkan dengan apa yang dibutuhkan masyarakat desa dalam kondisi kekinian desa tersebut.

Dalam Tahap sebelumnya rancangan peraturan desa yang telah diusulkan oleh pemerintah Desa Tegal diberikan kepada BPD Desa Tegal. Ranperdes tersebut diserahkan langsung oleh Muhtadin selaku sekretaris Pemerintah Desa Tegal di rumah Ahmad Saroh dan diterima langsung oleh Ahmad Saroh sendiri selaku Ketua BPD Desa Tegal. Setelah Ketua BPD Tegal menerima Rancangan Peraturan Desa tersebut, Ketua BPD Tegal mengadakan rapat bersama dengan perangkatnya guna membahas rancangan yang disampaikan oleh Pemerintah Desa Tegal tersebut secara internal BPD Tegal (Ketua BPD dan jajarannya). Setelah rapat tersebut barulah diadakan pembahasan dalam rapat gabungan.

\section{KESIMPULAN}

Dari penelitian yang dilakukan penulis dengan judul "Peran Badan Permusyawaratan (BPD) Dalam Penyusunan dan Penetapan Peraturan Desa Tegal Kecamatan Kemang Kabupaten Bogor ada beberapa hal yang menjadi kesimpulan yaitu: peran BPD dalam pembentukan peraturan desa pada tahap inisiasi diantaranya yaitu pengumpulan aspirasi, perumusan dan pengusulan. Pada tahap sosio politis BPD mengadakan rapat gabungan bersama pemerintah desa dan tokoh-tokoh masyarakat. Pada tahap yuridis peranan BPD Desa Tegal yakni BPD Desa Tegal yang melakukan penyusunan Rancangan Peraturan Desa tentang APBDesa tahun 2016 berdasarkan teknik perUndangUndangan (Legal Drafting).

Adapun berbagai faktor yang berpengaruh, adapun faktor yang berpengaruh dalam pembuatan Peraturan Desa No 2 Tahun 2016 tentang APB desa Tegal yaitu yaitu kurangnya inisiatif dari BPD dalam menetapkan rancangan peraturan Desa.. BPD yang ada selama ini kurang berperan dalam menjalankan fungsinya yaitu fungsi legislasi (penyusunan dan penetapan perdes). BPD Desa Tegal sangat minim menggunakan hak inisiatifnya dalam mengajukan rancangan peraturan desa. BPD selama ini cenderung pasif dan hanya menunggu adanya inisiatif dari Kepala Desa untuk menetapkan atau memberikan rancangan mengenai peraturan desa. Kurangnya koordinasi antara BPD dan Pemerintah Desa dalam hal penetapan peraturan desa. 
Rendahnya kualitas sumber daya manusia anggota BPD.

Jelaslah bahwa kualitas anggota BPD yaitu tingkat pendidikan dan latar belakang keilmuan yang terkait serta pengalaman dalam bidang pemerintahan juga sangat mempengaruhi kemampuan dan keterampilan teknis dengan bidang tugasnya seperti menyusun rancangan peraturan desa. Kurangnya pengetahuan dan pengalaman yang dimiliki sehubungan dengan bidang tugasnya, akan menyulitkan anggota BPD dalam menuangkan pikiran serta menganalisa suatu permasalahan guna menuangkannya dalam pembentukan peraturan desa.

\section{REFERENSI}

Afan, G. (2002). Politik Indoesia Transisi Menuju Demokrasi, Cetakan ketiga. Yogyakarta: Pustaka Pelajar.

Azra, A. (2000). Demokrasi Hak Asasi Manusia dan Masyarakat Madani. Jakarta: Prenada Media.

Berry, D. (1964). Pokok-pokok Pikiran dalam Sosiologi (thr Rules of Sociological Method) New York Free Press, 1964 edition) disunting oleh Drs. Paulus Wirutomo, Jakarta: Rajawali Press.

Bruce J. Perr IN. (1992). Suiciede Litigation Washington DC. America: Osychiatric Press.

Fauzan, A. (2010). Implementasi Peraturan Pemerintah No.72 Tahun 2005 tentang Pemerintahan Daerah terkait dengan peran Badan Permusyawaratan Desa dalam dalam Penetapan dan Penyusunan Peraturan Desa Di Desa Wanasari Kecamatan Dumeling Kabupaten Brebes.
Semarang: Ilmu Hukum Program Pascasarjana UNDIP.

Fauzan, M. (2006). Hukum Pemerintahan Daerah, Kajian Tentang Hubungan Keuangan Antara Pusat dan Daerah. Yogyakarta: UII Press.

http.blogspot.com/2008/11/teori

Pembagian Kekuasaan.htm. diakses pada 16 November 2016 pkl 22.00

Indrati, M. F. (2007). Ilmu perundangUndangan 2. Yogyakarta: PT.Kanisius.

Kelsen, H. (2006). Teori Umum Tentang Hukun dan Negara. Bandung: Nusamedia dan Nuansa.

Koentjoroningrat. (1964). Pengantar Antropologi. Jakarta: Universitas Negeri Jakarta.

Koswara, E. (2001). Otonomi Daerah untuk Demokrai dan Kemandirian Rakyat, Jakarta: Yayasan Pariba.

Kushandajani. (2008). Otonomi Desa Berbasis Modal Sosial dalam Perspektif Sosio Legal. Semarang: Jurusan Ilmu Pemerintahan FISIP UNDIP.

Lopa, B. (1987). Permasalahan dan Penegakan Hukum di Indonesia. Jakarta: Bulan Bintang.

Mahfud MD. (2006). Membangun Politik Hukum Menegakkan Konstitusi. Jakarta: Pustaka LP3ES.

Mahfud, MD. (1999). Hukum dan Pilar-Pilar Demokrasi. Yogyakarta: Gama Media.

Makalah fakultas Keguruan dan Ilmu Pendidikan. (2011). "Pendidikan Kewarganegaraan" Universitas Pamulang.

Manan, B. (200). Wewenang Propinsi, Kabupaten dan Kota Dalam Rangka Otonomi Daerah. Bandung: Makalah Pada Seminar Nasional Fakultas Hukum Unpad. 
Mardiasmo. (2002). Otonomi dan Kebijakan Keuangan Daerah. Yogyakarta: Andi.

Mariun. (1975). Asas-asa Hukum Pemerintahan, Yogyakarta: UGM.

Miriam Budiarjo. (1985). Dasar-Dasar Ilmu Politik. Jakarta: Gramedia.

Mulyadi, A. (2005) Landasan dan Prinsip Hukum Otonomi Daerah Dalam Negara Kesatuan RI. Jakarta: Prestasi Pustaka.

Murdopo, A. \& Megawati. (2006). Parlemen Bilateral dalam Sistem Ketatanegaran Indonesia. Yogyakata: UAD Press.

Mustari, P. (1999). Otonomi Daerah Dan Kepala Daerah Memasuki Abad XXI. Jakart: Gaya Media Pratama.

Peraturan Pemerintah Nomor 43 Tahun 2014 Tentang Desa.

Peraturan Pemerintah Nomor 72 Tahun 2005 Tentang BPD.

Peraturan Pemerintah Republik Indonesia Nomor 43 Tahun 2014 Tentang Peraturan Pelaksanaan UndangUndang Nomor 6 Tahun 2014 Tentang Desa.

Permendagri no. 29 tahun 2006 Tentang pembentukan dan mekanisme penyusunan perdes, tersedia di: www.kemendagri.go.id

/dmdocuments/

permendagri_26_2006_ penyusunan perdes. Pdf: diunduh pada tanggal 11 februari 2017 pukul 20.30 WIB.

Permendagri Nomor 110 Tahun 2016 Tentang BPD.

Permendagri Nomor 111 Tentang Pedoman Teknis Peraturan Desa.

Permendagri Nomor 29 Tahun 2016 Tentang Pedoman Pembentukan dan mekanisme Penyusunan Peraturan Desa.
Ridwan HR. (2006). Hukum Administrasi Negara. Jakarta: PT. Raja Grafindo Persada.

Saragih, M. K. B. R. (1978). Susunan Pembagian Kekuasan Menurut UUD 1945. Jakarta: Gramedia Pustaka Utama.

Saragih, M. K. B. R. (1978). Susunan Pembagian Kekuasan Menurut UUD 1945. Jakarta: Gramedia Pustaka Utama.

Saragih, M. K. B. R. \& Kusnadi, M. M. (2000). Ilmu Negara. Jakarta: Gaya Media Pratama.

Siswanto, S. (2006). Hukum Pemerintahan Daerah di Indonesia. Jakarta: Sinar Grafika.

Soehino. (1980). Ilmu Negara. Yogyakarta: Liberty.

Soekanto, S. (1990). Sosiologi Suatu Pengantar. Jakarta: PT. Remaja Grafindo Persada.

Soekanto, S. \& Mamudji, S. (1990). Penelitian Hukum Normatif suatu tinjauan singkat. Jakarta: CV. Rajawali.

Soemantri, S. (1992). Bunga Rampai Hukum Tata Negara Indonesia. Bandung: Alumni.

Taneko, S. B. (1968). Konsepsi Sistem Sosial Indonesia, Jakarta: CV. Fajar Agung.

Thalib, D. (2000). Kedaulatan Rakyat Negara dan Konstitusi. Yogyakarta: Liberty.

Undang- Undang Dasar Republik Indonesia Tahun 1945.

Undang-Undang Nomor 12 Tahun 2008 Tentang Pemerintahan Daerah.

Undang-Undang Nomor 23 Tahun 2014 Tentang Pemerintahan Daerah. 
Undang-Undang Nomor 6 Tahun 2014 Tentang Desa.

Viktor M, S. (1994). Hukum Administrasi Pemerintahan di Daerah. Jakarta: Sinar Grafika.

Wasistiono, S. \& Tahir, M. I. Prospek Pengembangan Desa. Bandung: CV. Fokus Media.

Widjaja, H.A.W. (2004). Otonomi Desa Merupakan Otonomi Yang Asli, bulat, dan Utuh. Jakarta: PT. Raja Grafindo Persada. 